\title{
HUNTING PRODUCTIVE WORK
}

\author{
PAUL COCKSHOTT (WPC@DCS.GLA.AC.UK) AND DAVE ZACHARIAH \\ (DAVEZ@KTH.SE)
}

\begin{abstract}
The paper summarises the definitions of productive labour derived from Smith and Marx. It attempts to develop a more general definition deriving from the theory of relative surplus value. The implications of the new definition for the examination of highly socialised capitalist economies like Sweden are examined.
\end{abstract}

The crew was complete: it included a Boots

A maker of Bonnets and Hoods

A Barrister brought to arrange their disputes

And a Broker to value their goods

(Lewis Caroll, Hunting of the Snark)

In this paper we want to address the perenially controversial question 'what is productive work'?

It is a question that stirs up emotions since nobody likes to be labeled unproductive and some would like to avoid the concept altogether, but try as one will, it repeatedly crops up not just in theory but in practical political discourse. We start by considering the views of two very eminent and very late economists, Prof Smith and Dr Marx. We then go on to present informally an alternative defi nition to those advanced by these giants. We develop this more formally and, using the example of Sweden compare the 
implications of using different criteria for the analysis of the working population. Finally we discuss the extent to which our defi nition of productive work can be reconciled with those of Smith and Marx.

\section{Illustrious ANCESTRY}

The idea of productive and unproductive labour was introduced by Adam Smith in 1776.

There is one sort of labour which adds to the value of the subject upon which it is bestowed: there is another which has no such effect. The former, as it produces a value, may be called productive; the latter, unproductive labour. Thus the labour of a manufacturer adds, generally, to the value of the materials which he works upon, that of his own maintenance, and of his master's profi t. The labour of a menial servant, on the contrary, adds to the value of nothing. Though the manufacturer has his wages advanced to him by his master, he, in reality, costs him no expence, the value of those wages being generally restored, together with a profi $t$, in the improved value of the subject upon which his labour is bestowed. But the maintenance of a menial servant never is restored. A man grows rich by employing a multitude of manufacturers: he grows poor by maintaining a multitude of menial servants. The labour of the latter, however, has its value, and deserves its reward as well as that of the former. But the labour of the manufacturer fi xes and realizes itself in 
some particular subject or vendible commodity, which lasts for some time at least after that labour is past. It is, as it were, a certain quantity of labour stocked and stored up to be employed, if necessary, upon some other occasion. That subject, or what is the same thing, the price of that subject, can afterwards, if necessary, put into motion a quantity of labour equal to that which had originally produced it. The labour of the menial servant, on the contrary, does not fi $\mathrm{x}$ or realize itself in any particular subject or vendible commodity. His services generally perish in the very instant of their performance, and seldom leave any trace or value behind them for which an equal quantity of service could afterwards be procured. (Adam Smith, The Nature and Causes of the Wealth of Nations, Book II, Chapter III)

Almost a century later, the idea was re-defi ned by Karl Marx:

Productive labour, in its meaning for capitalist production, is wage-labour which, exchanged against the variable part of capital (the part of the capital that is spent on wages), reproduces not only this part of the capital (or the value of its own labour-power), but in addition produces surplus-value for the capitalist, It is only thereby that commodity or money is transformed into capital, is produced as capital. Only that wage-labour is productive which produces capital. (This is the same as saying that it reproduces on an enlarged scale the sum of value expended on it, or that it gives in return 
more labour than it receives in the form of wages. Consequently, only that labour-power is productive which produces a value greater than its own.) (Karl Marx, Theories of Surplus Value, Vol 1, Chapter IV)

These defi nitions of productive labour by Marx and Smith are very similar. Marx's was a subset of Smith's since Smith gave3 two criterion which are not identical. His fi rst criterion was equivalent to Marx's :" the labour of a manufacturer adds, generally, to the value of the materials which he works upon, that of his own maintenance, and of his master's profit.", thus productive labour is that which, being employed by capital, produces a profi $\mathrm{t}$. According to Marx, Smith has an second defi nition, that productive labour must be embodied in a durable vendible commodity: "the labour of the manufacturer fi xes and realizes itself in some particular subject or vendible commodity, which lasts for some time at least after that labour is past." Marx criticised this defi nition for abstracting from the social form in which the labour is performed and betraying a physiocratic heritage.

We want to argue that neither Smith nor Marx's defi nitions are complete though both are substantially correct and that Smiths durable commodity concept hints at a more satisfactory conceptualisation of productive labour.

A problem with Marx's formulation is that whilst it readily categorises the self employed, state offi cials or parsons as unproductive, it runs into diffi culties with some other categories. For instance are bank employees or the workers in advertising agencies productive or unproductive. The advertising agency clearly produces a commodity - adverts, the sale of which pays its employees wages and returns a profi t on top. At fi rst sight they would 
appear to be productive. Similarly it can be argued that bank employees produce a commodity 'fi nancial services' and that their labour earns the bank a profi t.

There are counter arguments, that the accounts of the banks show that bank charges - the presumable payment for fi nancial services - are insuffi cient to cover the banks wage bills and that the residual has to be met out of interest payments. It is harder to justify labeling advertising copywriters as unproductive on Marx's defi nition. Smith's 'durable commodity' criterion would eliminate bank employees, but leave copywriters as productive, since advertising copy can last for some time after the labour on it is past.

One might argue that bank labour and advertising were non-productive because they were merely concerned with the transfer of property between owners rather than with the production of fi nal consumer goods, but this would go beyond what either Smith or Marx formally defi ned. It is pretty clear that Marx did not regard the labour of bank employees as productive, since they were assumed to be paid out of interest and interest was taken to be a deduction from surplus value in capitalist industry and agriculture. It is hard not to conclude that conventional Marxist categorisations like that of Shaikh and Tonak, are using some unstated premises beyond what is explicit by Marx.

"Productive labour is the production labour employed in capitalist production sectors: agriculture, mining, construction, transportation and public utilities, manufacturing, and productive services (defi ned as all services except business services, legal services, and private households; ...). It excludes 
nonproduction labour (sales, etc.) employed in the production sectors such as trade or fi nance. Total productive labour is the sum of the production workers in each production sector. Total unproductive labour is the sum of nonproduction workers in the production sectors and all workers in the nonproduction sectors",(Shaikh and Tonak, Measuring the Wealth of Nations, p. 295).

Why should legal services not count as productive if the law fi rms employ salaried clerks and return a profi t for their partners?

Given that one accepts that activities like advertising and retailing are themselves unproductive it follows that any labour they employ must also be unproductive. But this begs the question as to why advertising and retailing are unproductive. We do not believe that this question can be answered at the level of exchange value. It requires us to look beyond the representation of products as exchange values to their role in the overall material process of reproduction.

Another problem with the conventional defi nition is thatIt is predicated upon an assumption that the social formation is a pure capitalist mode of production. For social formations containing a combination of modes of production this is not necessarily an adequate categorisation.

It has peverse results such as workers in government direct labour departments building roads being unproductive, when the same work done by private contractors is productive. Now clearly in the case of the private contractors, a profi $\mathrm{t}$ is earned and so either: 
(1) The private contractors have been overpaid, or have under performed in road quality.

(2) They have paid their workers less

(3) They have used less labour due to use of more machinery or less wated time.

Whilst the transfer to private contractors may result in an increase in the social surplus product (cases 2,3) this is not necessarily the case.

In any case, the product, the road is a directly social good not assuming the form of a commodity. To the extent that a large part of the social product takes this form, as it has at times in some European countries, it would appear that the economy becomes increasingly unproductive. This comes from a focus only on what is productive for capital. Whilst in Smith and Marx's day, such a focus was both understandable and sided with progress - since the capitalist sector was the most advanced part of the economy. To continue with such a focus today leaves one in danger of theoretically siding with neo-liberal reaction. In mixed economies containing both capitalist and socialist elements, we do not want to side with the neo-liberals in defi ning the public educational or health systems as unproductive. In practical political economy we need a defi nition of productive labour that goes beyond a capitalist perspective. We need a defi nition that defends the more advanced social relations of our time, just as Smiths defi nition did in the 18 th century.

A more general theory of productive labour should, when applied to mixed capitalist and feudal social formations reproduce Smith and Marx's practical categorisations, but when applied to modern mixed economies 
should recognise the productive character of some public rather than private labour. The property of labour being productive for capital will then be seen as a historically specifi c expression of the role that some types of labour play in social reproduction. With changes in social relations whether social democratic, or socialist, the category of productive labour remains relevant, but it can no longer be defi ned in terms of labour being employed by capital.

We believe that it is possible to reconstruct a rational and unambigous defi nition of productive work by going back to Smith's original intentions. As we do this we will see that Marx and Smith were not wrong, only a bit imprecise. We aim to produce a defi nition of productive labour which, when applied to a purely capitalist economy, will produce essentially the same labeling of activities as productive of unproductive as Marx or Smith would have done, but which can also be applied to non-capitalist or only partially capitalist economies.

Smith's introduction of the concept of uproductive labour has to be seen in the context of a polemic against the aristrocracy and in favour of the manufacturing bourgeoisie in 18th century Scotland. The dissipation of part of the surplus product by an idle and licentious aristocracy employing small armies of personal retainers meant that these people were not employed building canals, roads or steam engines. If the surplus product was consumed unproductively, as had been the case under pre-capitalist economic formations, then the productivity of labour improved at a snails pace from century to century. If instead, it were reinvested in capital goods, then the 
productivity of labour, and thus national wealth grew in geometric progression. We believe that this concern with capital accumulation was at the heart of the original concept of productive labour. From it, we believe sprung Smith's insistence that productive labour must be embodied in a commodity that persists. If your focus is on the improvement of production, an improvement embodied in roads laid, canals dug, mines sunk, ships built then a pre-occupation with lasting commodities was understandable. Accumulation of capital is an instance of the accumulation of value. Value can only accumulate if it persists through time. It can only persist through time if it has some underlying material form that lasts through time. This means it must accumulate as commodities. You can accumulate value as money, but only insofar as that money takes the form of gold or silver, which by their nature are well suited to persist through time. No other accumulation of money is an accumulation of value or of capital. In Smith's day the Scotish economy already relied largely on banknotes and accounts rather than gold. A growth of M1, the mass of banknotes and current accounts, is merely a measure of the growth of a particular form of debt. A growth in debt involves a zero accumulation of value and thus of capital. But an accumulation of gold and silver in Scotland could only be achieved by an export of tangible commodities, thus it was reasonable to see the production of persistent commodities as a pre-condition for any accumulation of capital.

The concern with capital accumulation persisted in Marx, with his insistance that the production of surplus value was the sine qua non of productivity. But in his own analysis Marx failed to fully analyse the implications 
of this stipulation. What does it mean to produce surplus value, and is this identical to earning a monetary profi t?

There are two ways that surplus value can be produced. The working day can be lengthened, what Marx termed absolute surplus value, or technical innovation can reduce the number of hours necessary to produce the real wage, relative surplus value. In a developed capitalist economy the latter is the most important. This process of production of surplus value is tied up with the very improvements in productivity that require persistent capital investment - Smith's concern. Note that the production of relative surplus value is an economy wide phenomena. When cotton mills cheapened clothing, they enabled the same real wage to be met with less money. The benefi ciaries were not just the mill owners but all employers who could now pay lower wages. Relative surplus value is distal not proximate.

In the main therefore, to say that labour is productive of surplus value is to say that it is productive of relative surplus value, which means that it must be:

(1) Susceptible to technical advance.

(2) Produce a commodity that contributes to the real wage.

In what follows we will argue that it is the position that workers play in the process of social reproduction that determines whether their labour is productive. We shall explore the implications of asserting that:

Conjecture 1.1. labour is productive if it can produce relative surplus value. 


\section{INFORMAL PRESENTATION}

We shall fi rst relate some improving tales of the subject moral philosphy before going onto a more formal analysis.

2.1. The Bomber's lament. We will structure this argument using reproduction schemes derived from those given by Marx in vol II of Capital. Consider a 3 department model, with $\mathrm{I}=$ means of prod II= workers consumption, III= all other products. Many of the categories of activity traditionally classifi ed as unproductive, soldiering, priestcraft, advertising, personal servants etc would fall into sector III. Sector III would also include some activities not traditionally treated as unproductive such as the production of Learjets and luxury Yachts, the manufacture of Hydrogen bombs and warships. We would argue that no technical change in dept III can increase the mass of sv and that the whole sector is unproductive.

To take a gratuitously horrifi c example, consider the advances that occured in the manufacture of hydrogen bombs, such as the use of Lithium deutride rather than liquid deuterium in their manufacture circa 1957. Would this technological revolution increase the rate of surplus value?

No, because hydrogen bombs did not enter into the real wage, so the ratio of necessary to surplus labour would not change. Any cheapening of bombs just meant that the state could afford more of them. But what if the state had been content with the same number of cheaper bombs and laid off workers in its bomb factories?

It might seem that this would reduce $v_{3}$ relative to $s_{3}$ and so increase the rate of surplus value in the economy as a whole. But this is not the case. 
If we look at the reproduction equations we see the size of the output of dept III is determined in sectors I and II. Under simple or extended reproduction:

$$
\begin{array}{ll}
\text { total sv } & \text { dept III } \\
s_{1}+s_{2}+s_{3} & \geq c_{3}+v_{3}+s_{3} \\
s_{1}+s_{2} & \geq c_{3}+v_{3}
\end{array}
$$

The surplus value produced in sectors I and II is materialised as the means of production and wage goods used in sector III. Bearing this in mind, consider 3 possible results of workers being laid off from the bomb industry:

(1) The former bomb makers are re-employed in sector III. Then $v_{3}$ will remain unchanged as will the total surplus value. What happens is that the physical form of sector III's output is changed whilst its value magnitude remains the same.

(2) If they are redeployed to dept II, then the total working day spent on wage goods has risen and the net effect must be a fall in the rate of surplus value.

(3) If they are redeployed to department I then $s_{1}$ rises but this is conpensated by a decline in $s_{3}$ so net surplus value is unchanged. However the surplus is now materialised as constant capital indicating an increase in accumulation.

It is thus clear that an improvement in technology in department III can not increase the mass of surplus value. Since the conditions of labour in dept III do not alter the total surplus value we conclude that, generalising Marx's concept of unproductive labour, the whole of department III is unproductive. 
The labour of advertising, for example, since it does not enter into the real wage ( output of dept II ) must fall into dept III and be paid for out of the surplus raised in depts I and II.

The productivity of depts I and II determine the potential size of dept III which is parasitic on them. The big increases in productivity of industry in the 2 nd half of the 20th century led to substantial rise in the size of sector III, since only part of the gain in productivity was realised as higher real wages, a large part went as more surplus value.

2.2. The armourer's tale. We will now argue that the social form of labour in department III is also irrelevant.

Almost all economists would agree that the activity of the Army and Navy are unproductive. By extension it will probably be agreed that the former Royal Armoury and Royal Dockyards which supplied the Army and Navy with cannon and ships were unproductive. Now consider the situation that occured when the government sold off the Royal Armouries and Royal Dockyards to private industry. It might appear that that, following Marx's defi nition, the dock workers and armourers must have suddenly become productive.

If we accept this we would have the remarkable result that an activity that was once an unproductive use of societies resources, had, by the magic of privatisation, become a productive and useful labour. To accept this would be to reduce the concept of productive labour to the most banal appologetics, but on both Smith and Marx's defi nition there seems no way out. Rosyth Docks PLC sells the Navy a vendible and durable commodity - ship repairs. It recieves money for this and makes a profi t. Both Smith's criterion 
and Marx's criterion point to the dockers and armourers becoming productive on privatisation. But has this transfer of social form actually increased the total surplus value produced.

Let us consider the situation the day after the private owner takes over, and before they have done any re-organisation of production since we have already shown that no improvement in productivity in a Dept III activity can raise surplus value. Here we are concerned with whether the change in employer produces more surplus value.

It there is no rise in productivity, any profi t comes from the Navy paying more for ship repairs. Suppose that an hour's labour created a monetary value of $£ 10$, but the dock workers were paid $£ 4$ an hour. The Navy would previously have paid $£ 400,000$ for a repair job that took 100,000 hours. After privatisation they must pay $£ 1$ million. The dockyard company has made a profi t of $£ 600,000$. But how does the navy pay for this extra $£ 600,000$ ?

Obviously the chancellor has to raise taxes. If we follow a 'classical' approach to taxes we would assume that these taxes fall on the surplus product.

All taxes must either fall on capital or revenue. If they encroach on capital, they must proportionably diminish that fund by whose extent the extent of the productive industry of the country must always be regulated; and if they fall on revenue, they must either lessen accumulation, or force the contributors to save the amount of the tax, by making a 
corresponding diminution of their former unproductive consumption of the necessaries and luxuries of life. (David Ricardo, Principles of Political Economy and Taxation, Chapter 8 )

Ricardo here implicitly assumes by 'revenue' the revenue of the propertied classes. He goes on to argue that taxes on consumer goods 'raw produce' ends up as a tax on profi ts and that:

A tax on wages is wholly a tax on profits, a tax on necessaries is partly a tax on profi ts, and partly a tax on rich consumers. The ultimate effects which will result from such taxes then, are precisely the same as those which result from a direct tax on profi ts. (David Ricardo, Principles of Political Economy and Taxation, Chapter 16)

If the new taxes fall on profi ts then all that has happened is that $£ 600,000$ has been transfered from the capitalist class in general to the new owners of the dockyard. No additional surplus value has been produced. Thus contrary to initial appearances privatisation creates no new surplus value. If one abstracts from social form this is not surprising since no change has occured to alter the ratio of necessary to surplus labour.

If we allow that some of the new tax will fall on wages and that contrary to Ricardo, wages do not rise to compensate, then what has happened is a depression of the price of labour power below its value. This again is not the result of some new productivity of the labour in the dockyard, but an expression of the general power of the state to appropriate revenue. If we were to say that the state can 'produce' a surplus by raising taxes, then the 
whole distinction between productive and unproductive labour collapses. One could as well have said that all the King's horses and all the King's men were productive since their upkeep forced the King to levy taxes and thus 'produce' a surplus.

We can now advance a thesis about social form and unproductive labour:

Theorem. No change in juridical relations can change what was formerly unproductive labour into productive labour.

We will illustrate this with a Noble tale.

2.3. The Duke's story. The Duke of Atholl maintains the only remaining private feudal army in Europe - the Atholl Highlanders. They and similar feudal retainers were the original target of Smiths polemic against unproductive labour. We do not believe that they would become productive were he to form them as a mercenary company 'Atholl Highland Soldiers Plc.', owned of course by his Highness, and then use the revenues of his estate to hire them to guard his castles.

" A man grows rich by employing a multitude of manufacturers: he grows poor by maintaining a multitude of menial servants. "

But what if his Highness were to hire his mercernary company out to perform ceremonial duties at the palaces of his Peers, the Dukes of Buccleugh, Sutherland or Lancaster?

The Atholl Highlanders would no longer be a drain on his estate but a source of income. Has this wheeze made them productive?

Smith would unhesitatingly have said "No". No durable commodity issues, so there is no productive labour. As soon as one looks at the National 
Accounts the illusion of the troop's industry is dispelled. They are still maintained out of rent, a surplus produced by the tennant farmers of the Noble Lords. The fact that the Dukes have banded together to bear the cost of soldiers alters this not one jot.

This is true of the Duke of Atholl, and it is true of a nation as a whole. If a nation maintains a large military establishment, a large part of its best engineers are involved not in the design and production of capital goods but in the production of machines which do not constitute capital. This slows down capital accumulation in those countries. The person hours spent on Trident submarines and aircraft carriers are hours not spent modernising the means of production.

\section{Formal PRESENTATION}

3.1. The production matrix. Let us defi ne a sector as an activity involving labour and material resources, integrated with other such activities. Productive sectors must be considered 'necessary' or 'basic' in some specific economic sense because the concept implies that a fraction of its surplus supports the unproductive ones. We consider an economy consisting of $n$ sectors. The level of aggregation is not necessary to specify here. Data published by national accounting agencies usually contain about fi fty to one hundred sectors, but we might defi ne our economy in greater detail.

The production relations between the $n$ sectors form a $(n \times n)$ production matrix A, describing the technical conditions of production. ${ }^{1}$ A matrix

\footnotetext{
${ }^{1}$ It can be empirically approximated for some reasonable time period using input-output tables of the economy.
} 
element $a_{i j}$ is defi ned as the output of sector $i$ necessary to produce a unit of output from sector $j$.

The production matrix will obviously change its structure and values over time as economic patterns alter, innovations are applied, new sectors are formed and old ones disappear. It should be emphasized that it strictly deals with inputs of production. An electrician might need a bank account, but there is no technological reason why she couldn't perform her service without consulting a bank.

3.2. The workers' consumption vector. All sectors in the economy require some set of workers. Let $\mathbf{c}$ be the $(n \times 1)$ worker's consumption vector that describes the bundle of goods and services they consume for some time period. ${ }^{2}$ An element $c_{i}$ denotes their consumption of sector $i$ :s output. There will be several sectors with zero input in $\mathbf{c}$.

3.3. A simpler definition. With a production matrix A and workers' consumption vector c for some time period, we can handle several types of economies with different mixes of relations of production. This makes it possible to propose a more general defi nition of productive sectors, one which applies to socialist and mixed economies as well as capitalist ones.

To restate what has been said in part 2, it is not sensible to view sectors that produce the workers' consumption bundle as unproductive. It is improvements in these that allow relative surplus value to be produced. Our conjecture 1.1 ties productive labour to the production of relative surplus value. Further more it is clear that while workers don't consume jumbo

\footnotetext{
${ }^{2}$ Excluding the fraction of ruling groups who actually work, such as 'top management' in modern capitalist firms. Depending on their privileges, their consumption will diverge significantly from the workers in the sector.
} 
jets, they do consume air travel that requires them. In turn, the production of jumbo jets requires various components that you wouldn't find in any household's shopping list.

There exists a bundle of goods and services necessary to sustain the worker's consumption bundle, which we can write as a $(n \times 1)$ vector $\mathbf{c}^{*}$. It is defi ned by the following relation: $\mathbf{c}^{*}=\mathbf{A} \mathbf{c}^{*}+\mathbf{c} \Rightarrow \mathbf{c}^{*}=(\mathbf{I}-\mathbf{A})^{-1} \mathbf{c}$. (Here $\mathbf{I}$ is the $n \times n$ identity matrix.) An element $c_{i}^{*}$ denotes the quantity of sector $i$ :s output required to sustain the worker's consumption bundle. This also provides a rational basis for a defi nition of productive sectors:

Theorem. Sector $i$ is productive if $c_{i}^{*} \neq 0$, i.e. any sector that directly or indirectly sustains the workers' consumption bundle is productive.

3.4. Theoretical implications. If our economy is specifi ed at industry level we can tell what industries are productive. If it is in greater detail we will gain information on what functions of it are productive. Our defi nition has some theoretical implications that are addressed below:

(1) If social production and consumption can be described by $\mathbf{A}$ and c, the defi nition is general and can be applied to a large variety of economies, including state capitalist enterprises, public sector, workers' co-operatives, peasants producing for markets and the Soviettype economies. Changes in $\mathbf{A}$ and $\mathbf{c}$ also make it logically possible for some sectors to shift from unproductive to productive, or vice versa, over time. Contrawise, a change in the form of ownership of the means of production does not itself shift sectors from productive to unproductive. 
(2) The total labour-time performed by the workers in the productive sectors can now be divided into 'necessary labour' required to produce their part of the consumption bundle and 'surplus labour' that forms the material basis for the surplus product. Productive labour not only supports the entire working population and its dependents, but also the ruling classes of the political-economic system. To the extent that capitalist production dominates, the ratio of surplus to necessary labour can be held equivalent to the 'rate of surplus value' as Marx does in the fi rst volume of Capital.

(3) In modern capitalist economies the more obvious unproductive sectors are public administration and the police-military apparatus, but also capitalist activities such as armaments, private guards, wholesale trade, advertisement, fi nancial and juridical services, luxuries etc.

(4) Some sectors which have traditionally been treated as unproductive in Marxist discourse, such as parts of state education, may now be seen to be productive since they enter indirectly into the reproduction of the labour force and thus affect the ratio between necessary and surplus labour.

It is clear that such sectors or subsystem of sectors must be fi nanced by a fraction of the surplus of productive ones, since they don't serve as input in the production of those goods and services. The surplus of the productive sectors is thus the upper limit to the size of unproductive activities. Any improvement in their labour productivity will not either increase the rate 
of surplus value. ${ }^{3}$ As an increasing fraction of surplus labour is devoted to support them, a diminishing fraction becomes available for capital accumulation which would modernise production and reduce the number of hours necessary to produce the real wage; this would also make room for the working class to raise its living standard. What are the benefi ts of more advertising, banking, private guards, bombers or private jets for the working people and their dependents? Certainly not those enjoyed by the propertied classes.

We can also deduce a corrollary from theorem 3.3.

Corollary 3.1. If a labour activity is productive then it enters directly or indirectly into the production of every other product in the economy.

This is analogous to Sraffa's idea of the Standard system (Sraffa 1960). Recall that the standard commodity was a commodity bundle. It was produced by a sub-section of the economy, the Standard system, in such a way that the ratios of the outputs of the Standard System was the same as the ratio of the inputs required to produce it. Sraffa argued that

It can be said that in any actual economic system there is embeded a miniature Standard system which can be brought to light by chipping off the unwanted parts. (Sraffa, 1960, Chap IV)

The components of the Standard commodity are used directly or indirectly as inputs to all other commodities. The Standard commodity has associated with it avalue $=1+R$ where $R$ is the Standard ratio or Maximum rate of

\footnotetext{
${ }^{3}$ The economic impact of unproductive activities may however vary. See for example 'military-keynesianism'.
} 
profi $\mathrm{t}$ - the rate of profi t occuring if wages are zero. If on grounds of realism we do not allow ourselves to consider zero wages, then the concept of the Standard system can be extended by including a set of processes that reproduce labour of different specialisms. The inputs into these processes include both the real wage and the educational and training activities necessary to produce labour. We model this with an extended reproduction matrix $R$ with additional rows and colums representing the labour producing processes. We want an extended analogy to the Standard system made up of all the productive activities in the economy which we will term the Productive system.

A constructive derivation of the Productive system is as follows $L, B$ are two sets of integers designating rows in the extended reproduction matrix , and $S$ is the set of rows entering into the Standard commodity.

Algorithm 3.2. 1. Initialise $B$ to be the same as $S$. Initialise L to be the direct elements of the real wage.

2. Set $L$ to be the union of $L$ and B. Clearly any element of the standard commodity must by definition enter into the real wage.

3. for all the $j$ in L go through each entry in row $j$ of the input output matrix if the entry $r_{j i}$ is non-zero and if industry $i$ is not already included in the real wage then add industry $i$ to $B$.

4. if $L \neq B$ then goto step 2 again, otherwise finish.

At the end of this algorithm $B$ will be the set of production processes comprising the Productive system. This will include some educational processes but not others. For example, seminaries and offi cer training colleges would not fall within the productive system but an engineering college or a 
primary school would. It will include some consumer goods but not others. Baking would be productive but making goods which are not consumed by the workers because they are prohibitively expensive such as Rolls-Royces would not. Of course such distinctions are historically relative, at one time automobiles were expensive luxuries that did not enter into the real wage. With the passage of time this changed.

Either the automobile is an expensive luxury item for a few people, and hence in the long run not very important for the economy as a whole, or it is destined to have the enormous impact on the economy which by its very nature it can have. Then, however, it must be transformed from a luxury item for the few to something that everyone uses. And I fear that even today the German automobile industry has not realized that the overall development of German automobile production cannot really succeed, unless prices match the income level of the purchasers it targets.

Hitler's Speech of February 151936 at the German Motor show at which he announced the Volkswagen project.

Despite the movement of more and more goods into the real wage, there always remains a differentiation by price of goods into luxuries and necessities, since without this differentiation the propertied classes would be bereft of a means of expressing their social superiority.

Note too, that even self employed farmers can be productive. A productive worker does not need to be a wage labourer, since relative surplus value is produced in all sectors that can contribute to the real wage whether these 
are capitalist or not. Improvements in farming technology, the use of machinery etc, greatly increased labour productivity on European farms in the second half of the 20th century. The labour necessary to produce food fell. This improvement in productivity occured both on capitalist and peasant farms. To the extent that improved techniques by the peasants cheapened wage goods, these same peasants contributed to the production of relative surplus value and were productive workers.

\section{EMPIRICAL IMPLICATIONS}

Let us see what the empirical implications are for our defi nition of productive labour, using employment statistics at industry level for Sweden for years 1987-2003. During this period the average employment was about 4.2 million people, or roughly half of the Swedish population. Employment dropped to about 3.9 million during the economic crisis of the 1990s. Many workers in the public sector were fi red when the 'one-way' crisis politics kicked in. Total employment has however recovered somewhat the latest years.

Employment in sectors as

1. wholesale, retail and commission trade,

2. fi nancial, real estate and other business services,

3. renting of machinery and equipment, activities of membership organisations

4. Public administration and defense, was considered unproductive on our defi nition. 
If one uses the conventional Marxist defi nition, however, three additional sectors must be added to this list; research and development institutions, education and health and social work services.

A signifi cant part of $R \& D$ institutions is government funded and they don't produce commodities as capitalist fi rms, nevertheless it is safe to say that the output of civilian R\&D enters indirectly in the production of the wage-bundle. In Sweden the overwhelming majority of workers in education and health and social work services are employed by the tax-fi nanced public sector.

Table 1 shows the estimated share of unproductive employment in Sweden for the years 1987-2003, using both defi nitions. As one can see there is a huge difference here. If one accepts the conventional Marxian defi nition then about $56 \%$ of the workforce was unproductive during this period. Using our defi nition the fi gure is about $29 \%$.

\section{CONCLUSiON}

We have given a more precise defi nition of productive labour. We presented it as an immanent critique of Marx's defi nition, using his ideas on relative surplus value, necessary and surplus labour time, and the reproduction schemes of vol II of Capital to tease out what it actually means to be productive of surplus value. The logic of this shows that whilst the general thrust of Marx's analysis on the subject is right, the implications are not always what they seem. In particular his critique of Smith's second definition of productive labour as labour embodied in a durable commodity is probably unjustifi ed. The thrust of Marx's criticism of Smith was that this second defi nition was invalid because it ignored the social form of the 
TABLE 1. Fraction of the workforce who are unproductive in Sweden using two different defi nitions

$\begin{array}{cccc}\text { Year } & \begin{array}{c}\text { Orthodox } \\ \text { Defi nition }\end{array} & \begin{array}{c}\text { New } \\ \text { Defi nition }\end{array} & \begin{array}{c}\text { Orthodox/ } \\ \text { New }\end{array} \\ 1987 & 0.529 & 0.267 & 1.983 \\ 1988 & 0.535 & 0.271 & 1.975 \\ 1989 & 0.537 & 0.274 & 1.960 \\ 1990 & 0.540 & 0.274 & 1.973 \\ 1991 & 0.549 & 0.278 & 1.974 \\ 1992 & 0.563 & 0.287 & 1.962 \\ 1993 & 0.573 & 0.286 & 2.000 \\ 1994 & 0.576 & 0.287 & 2.003 \\ 1995 & 0.571 & 0.285 & 2.000 \\ 1996 & 0.569 & 0.289 & 1.969 \\ 1997 & 0.566 & 0.293 & 1.929 \\ 1998 & 0.566 & 0.292 & 1.940 \\ 1999 & 0.568 & 0.293 & 1.938 \\ 2000 & 0.573 & 0.302 & 1.901 \\ 2001 & 0.580 & 0.307 & 1.889 \\ 2002 & 0.590 & 0.311 & 1.895 \\ 2003 & 0.597 & 0.312 & 1.910\end{array}$

Source: Statistics Sweden, 'Sysselsatta (AKU) efter näringsgren SNI2002 och tid'. Available at: www.scb.se

labour - whether it was wage labour or not. We think that Marx was overly restrictive in this, and that in fact changes in social form do not determine whether labour is productive or not. Instead, we argue that it is the position of the labour within the process of social reproduction that is crucial.

Smith's concern with the production of durable commodities, whilst an inexact formulation did hint at something important, that whether or not work is productive depends on what it produces.

Our conclusion is that productive labour includes all work necessary to the support of the direct producers. This conclusion is well grounded in input/output analysis and lends the concept of productive labour a modern progressive polemical edge. 


\section{REFERENCES}

[1] Foley, D. 1986, Understanding Capital: Marx'Economic Theory. Massachusetts, Harvard University Press.

[2] Marx, K. 1990, Capital, volume 1. [1867] England, Penguin Classics.

[3] Marx, K, Theories of Surplus Value, Vol 1,

[4] Mohun, S. 1999, Productive and unproductive: a reply to Houston and Laibman. Review of Radical Political Economy \#34, 2002, p.203-20.

[5] Moseley, F. 2003, Marxian Crisis Theory and the Postwar US Economy. Published in A.Saad-Filho (ed.), 'Anti-Capitalism: A Marxist Introduction', Pluto Press, 2003. http://home.mtholyoke.edu/ fmoseley/.

[6] Ricardo, D., Principles of Political Economy and Taxation

[7] Shaikh, A. and Tonak, A. 1994, Measuring the Wealth of Nations. Cambridge University Press.

[8] Smith, A., The Nature and Causes of the Wealth of Nations, [1776].

[9] Sraffa, P., 1960, Production of Commodities by Means of Commodities, Cambridge University Press.

[10] Savran, S and Tonak, A. 1999, Productive and unproductive labour: an attempt clarif cation and classifi cation Capital Class \#68, Summer 1999, p.113-52.

E-mail address: (wpc@dcs.gla.ac.uk),

Dept Computing Science, University of Glasgow, Glasgow G12 8QQ, SCOTLAND 